\title{
Cytogenetic and Molecular Changes in Leukemia among Atomic Bomb Survivors
}

\author{
NANAO KAMADA ${ }^{1}$, KIMIO TANAKA ${ }^{1}$, NOBUO OGUMA ${ }^{1}$ AND \\ KIYOHIKO MABUCHI ${ }^{2}$ \\ ' Department of Hematology, Research Institute for Nuclear Medicine and Biology, \\ Hiroshima University, Hiroshima \\ ${ }^{2}$ Department of Epidemiology, Radiation Effect Research Foundation, Hiroshima
}

(Received December 6, 1990)

\begin{abstract}
Atomic bomb survivors/acute leukemia/chronic myelocytic leukemia/chromosome/ras oncogene
Seventy five radiation-related leukemia patients in Hiroshima including 16 patients exposed to more than one Gray were cytogenetically examined. Statistical analysis of data on the frequencies of chromosomal aberrations in the survivor groups according to bone marrow doses by DS86 estimation revealed that the heavily exposed group tended to have significantly higher aberration rates compared to the non-exposed group. Furthermore, the chromosomal aberrations in the survivors were observed to be of a more complex nature and had the characteristic findings of secondary leukemia. These observations therefore suggest that patients with a history of heavy exposure to atomic bomb radiation had leukemic cells originating from a stem cell which had been damaged by irradiation at the time of the bombing as wcll as cells involved in complex chromosome abnormalities.

Molecular biologic studies on ras genes in acute and chronic leukemias and the ber gene in chronic myelocytic leukemia were performed in exposed and non-exposed groups. So far, no distinctive differences have becn observed in the frequency and sitcs of point mutations in $\mathrm{N}$ - and $\mathrm{K}$-ras genes or in the rearrangement of the bcr gene. Further, retrospective analysis using DNA from leukemia patients who developed this disease in the early period from atomic bomb radiation exposure would be useful for the clucidation of the mechanisms of radiation-induced leukemia.
\end{abstract}

\section{INTRODUCTION}

Several characteristic features of leukemias related to the atomic bomb have been firmly established by epidemiological studies: (1) the highest incidence of leukemia was observed between $8-10$ years after the bombing. (2) a strong correlation was found between the incidence of leukemia and the dose of radiation to which people were exposed; (3) the younger the individuals at the time of the bombing, the greater was the risk of leukemia during the early period, and (4) there was a predominance of myelocytic leukemia, especially of chronic myelocytic leukemia in Hiroshima as compared to Nagasaki.

Cytogenetic studies of bone marrow cells have been performed in survivors who were in good health and who did not suffer from leukemia or refractory anemia. Cytogenetic analysis in healthy survivors revealed a strong correlation between multiple chromosome 
aberrations and the doses of radiation, suggesting the possible involvement of chromosome abnormalities in radiation-induced leukemia ${ }^{1)}$. The present report describes the cytogenetic findings of 75 patients with acute non-lymphocytic leukemia (ANLL)/myelodysplastic syndrome (MDS) and 35 patients with chronic myelocytic leukemia (CML) among the survivors from an extended sample in Hiroshima in a Life Span Study (LSS). Molecular biologic findings in radiation induced leukemia were also presented in comparison with the findings in non-exposed leukemias.

1. Cytogenetic studies of leukemias among A-bomb survivors.

a. Acute non-lymphocytic leukemia (ANLL) and myelodysplastic syndrome (MDS)

Cytogenetic analysis was performed in 336 patients with ANLL/MDS for 27 years from September 1962 to March 1989. Patients who developed leukemia after September 1962 were cytogenetically examined. The control group included only patients who were born before August 1945. The radiation levels in exposed patients had been estimated by T65D dosimetry $^{2)}$ (later recalculated by DS86) ${ }^{3)}$ at the Radiation Effects Research Foundation (RERF) before they developed leukemia. Leukemia patients were divided into five groups according to their exposure status; those who received more than 1 Gray (bone marrow dose), 0.01-0.99 Grays, 0 Gray, "exposed" and "non-exposed". Fifty two patients belonged to the first three groups $(-1.0,0.01-0.99$ and 0$)$ and were the survivors of a sample group used for a Life Span Study (LSS) by ABCC/RERF which was established in 1950. Twenty three patients of the "exposed" group had been exposed at a distance of between 1.0 and $2.0 \mathrm{~km}$ from the hypocenter but were not included in the LSS sample without the doses estimated by DS86 dosimetry. The numbers of patients analysed in each group and the leukemia subtypes by FAB classification are shown in Table $1^{4)}$. Because of the similarity of the chromosome findings in the groups 0.01-0.99 Grays and "exposed", both groups were combined in the analyses.

Table 1. Numbers of Leukcmia Patients and FAB Classification ${ }^{1) 2)}$

\begin{tabular}{lrrrrrrrr}
\hline $\begin{array}{l}\text { DS86 marrow dose } \\
\text { group in Grays }\end{array}$ & M1 & M2 & M3 & M4 & M5 & M6 & MDS & Total \\
\hline $1.0 \sim$ & 2 & 4 & 0 & 1 & 1 & 5 & 3 & 16 \\
$0.01 \sim 0.99$ & 3 & 5 & 0 & 1 & 1 & 1 & 0 & 11 \\
0 & 11 & 6 & 0 & 1 & 3 & 3 & 1 & 25 \\
exposed $^{3)}$ & 5 & 2 & 3 & 1 & 1 & 2 & 9 & 23 \\
non-exposed $^{3)}$ & 62 & 72 & 25 & 24 & 13 & 30 & 35 & 261 \\
\hline
\end{tabular}

1) Study period from September 1962 to March 1989.

2) All blood smears from patients who developed leukemia before 1980 were reclassified and subgrouped according to the FAB classification.

3) Exposed at a distance of between 1.0 and 2.0 kilometers from the hypocenter but doses were not estimated by DS86 dosimetry. 
Table 2 shows the modal chromosome number and percentage of patients with chromosome aberrations in the exposed and non-exposed gioups. All patients who received more than one Gray of radiation showed clonal chromosome aberrations. The other three groups showed aberration rates of 52.9-60.9\%. There was a significant difference between the heavily exposed and other groups. Table 3 shows the chromosome aberrations and the estimated marrow doses and the type of leukemia in six patients who had been exposed to more than two Grays of atomic bomb radiation. Diagnosis of the six patients were two cases each of M2, M6 and MDS.

It was decided to regard trisomy, monosomy and deletion as one aberration and translocation and interstitial deletion as two aberrations. Table 4 shows the numbers of chromosome aberrations per stem line and the percentage of cases with more than three abnormalities. Seventy five percent of patients in the heavily exposed group had more than three chromosome abnormalities in the stem lines, representing more complex types of aberrations. A statistically significant difference was observed between the heavily exposed group and the other groups.

Chromosome aberrations in chromosomes 5 and/or 7 were observed in 6 of the 8 banded patients in the heavily exposed group. In other groups, patients having abnormalities of chromosome 5 and/or 7 were limited to within 30 percent (Table 5).

The specific chromosome abnormalities of $8 ; 21$ and 15;17 translocations were found in 29 of $89 \mathrm{M} 2$ patients $(32.6 \%)$ and in 15 of $28 \mathrm{M} 3$ patients $(53.6 \%)$. No cases with $8 ; 21$ or $15 ; 17$ translocations were found in the heavily exposed group. Thus ANLL/MDS patients exposed to more than one Gray showed a significantly higher incidence of chromosome aberrations, more complex types of aberrations and a higher incidence of aberrations in chromosomes 5 and/or 7 than that of non-exposed patients. The question arises why ANLL/MDS patients with a history of heavy exposure show increases in chromosome aberrations in their leukemic cells. Our previous results from a cytogenetic study on 31 healthy survivors who were exposed within 500 meters and had a median estimated dose of 2.5 Grays of $\mathrm{T} 65 \mathrm{D}$ doses, showed that $96.8 \%$ of survivors had chromosome aberrations.

Table 2.

\begin{tabular}{|c|c|c|c|c|c|c|c|c|c|c|c|}
\hline \multirow{2}{*}{$\begin{array}{l}\text { DS86 marrow } \\
\text { dose } \\
\text { (in Grays) }\end{array}$} & \multicolumn{9}{|c|}{ Modal chromosome number } & \multirow{2}{*}{$\begin{array}{c}\text { Total cases } \\
\text { analysed }\end{array}$} & \multirow{2}{*}{$\begin{array}{c}\text { Percentage of } \\
\text { patients with } \\
\text { chromosome } \\
\text { aberrations }\end{array}$} \\
\hline & 42 & 43 & 44 & 45 & $46(n)$ & $46(a b)$ & 47 & 48 & $\geqq 49$ & & \\
\hline $1.0 \sim$ & 2 & & & 2 & & 9 & & 2 & 1 & 16 & $100^{*}$ \\
\hline $\begin{array}{l}0.01 \sim 0.99 \\
\text { and "cxposed" }\end{array}$ & & & & 4 & 16 & 10 & 4 & & & 34 & 52.9 \\
\hline 0 & & & 2 & 3 & 11 & 6 & 2 & & 1 & 25 & 56.0 \\
\hline Non-exposed & 2 & 4 & 8 & 34 & 102 & 71 & 26 & 6 & 8 & 261 & 60.9 \\
\hline
\end{tabular}

${ }^{*} \mathrm{p}<0.001$ 
Table 3. Chromosome Aberrations in Heavily Exposed Leukemia Patients (2 Grays or morc)

\begin{tabular}{|c|c|c|c|c|c|}
\hline Case & Age/Sex & $\begin{array}{c}\text { Marrow } \\
\text { dose (Grays) }\end{array}$ & $\begin{array}{c}\text { Date of } \\
\text { onset }\end{array}$ & $\begin{array}{c}\text { Type of } \\
\text { leukemia }\end{array}$ & Karyotype \\
\hline 1 & $81 / F$ & 2,085 & Dec/1985 & M6 & $46, \mathrm{XX}, \operatorname{del}(7)(\mathrm{q} 11 \mathrm{q} 22), \operatorname{del}(20)(\mathrm{p} 12)$ \\
\hline 2 & $53 / \mathrm{M}$ & 2,187 & $\operatorname{Dec} / 1986$ & M2 & $\begin{array}{l}42, \mathrm{X},-\mathrm{Y},-1,-2,-5,-13,-13,-14,-15, \\
\quad-17,-19,-21,-22,+\operatorname{dic}(1 ; ?)(\mathrm{p} 32 ; ?), \\
\quad+\operatorname{dic}(2 ; ?)(\mathrm{p} 13 ; ?),+\operatorname{dic}(2) \mathrm{t}(2 ; ?)(\mathrm{q} 37 ; ?), \\
\quad \operatorname{del}(7)(\mathrm{q} 32), \mathrm{i}(8 \mathrm{q}), \operatorname{del}(9)(\mathrm{q} 22 \mathrm{q} 31),+\operatorname{der}(14) \\
\mathrm{t}(14 ; ?)(\mathrm{q} 32 ; ?),+\operatorname{der}(19) \mathrm{t}(11 ; 19)(\mathrm{q} 24 ; \mathrm{q} 13), \\
\quad+\operatorname{der}(22) \mathrm{t}(22 ; ?)(\mathrm{p} 11 ; ?),+\operatorname{mar} 1,+\operatorname{mar} 2, \\
\quad+\operatorname{mar} 3\end{array}$ \\
\hline 3 & $66 / \mathrm{M}$ & 2,474 & $\mathrm{Feb} / 1980$ & MDS & $48, \mathrm{XY},+17,+20, \operatorname{del}(5)(\mathrm{q} 12 \mathrm{q} 31)$ \\
\hline 4 & $80 / \mathrm{M}$ & 2,537 & Sept $/ 1978$ & M2 & $\begin{array}{l}42, X Y,-4,-4,-5,-8, i(8 q) / 46, X Y,-8 \\
\quad i(8 q),+22\end{array}$ \\
\hline 5 & $61 / \mathrm{M}$ & 4,094 & Dec/1976 & M6 & $45, X Y,-8,13 q+, 17 p+$ \\
\hline 6 & $72 / \mathbf{F}$ & 4,528 & April/1986 & MDS & $\begin{array}{l}46, \mathrm{XX},-10,-14,-20, \mathrm{i}(1 \mathrm{q}), \operatorname{del}(5)(\mathrm{q} 15), \\
\quad+\operatorname{der}(14) \mathrm{t}(3 ; 14)(\mathrm{q} 22 ; \mathrm{q} 22),+ \text { mar, + ring }\end{array}$ \\
\hline
\end{tabular}

Table 4.

\begin{tabular}{lrrrrrrrr}
\hline $\begin{array}{l}\text { DS86 marrow } \\
\text { dose group } \\
\text { in Grays }\end{array}$ & \multicolumn{6}{c}{ Number of chromosome aberrations per stem line } & \\
\cline { 2 - 7 } & 0 & $1-2$ & $3-4$ & $5-6$ & $7-8$ & $9-10$ & $11-$ & $\begin{array}{c}\text { \% of patients } \\
\text { with more than } \\
3 \text { abnormalities }\end{array}$ \\
\hline $1.0 \sim$ & 0 & 4 & 8 & 2 & 0 & 1 & 1 & $75^{*}$ \\
$0.01 \sim 0.99$ & 16 & 14 & 3 & 1 & 0 & 0 & 0 & 11.7 \\
$\begin{array}{l}\text { and "exposed" } \\
0\end{array}$ & 11 & 8 & 2 & 0 & 0 & 2 & 2 & 24.0 \\
Non-exposed & 102 & 90 & 38 & 8 & 6 & 6 & 11 & 26.4 \\
\hline
\end{tabular}

$* \mathrm{p}<0.05$

An average of $22.6 \%$ of bone marrow metaphases showed stable type aberrations. Thirteen out of 21 healthy survivors exposed at a distance of between $500-1,000$ meters from the hypocenter had chromosome aberrations to an average extent of $17.6 \%$ in the bone marrow cells. This means that survivors who were exposed within 1,000 meters from the hypocenter or 1-2 Grays exposure have about $20 \%$ chromosome aberrations in the bone marrow cells while remaining healthy. The cells with these chromosomal abnormalities without clonal formation may induce some abnormal events in the bone marrow and may also compete with cells in functionally normal and/or abnormal clones leading to the induction of leukemia ${ }^{1 \text {. }}$. Leukemia cells with increased chromosome abnormalities found in the heavily exposed 
survivors may have derived from some cells with karyotypic abnormalities prior to the development of leukemia.

b. Chronic myelocytic leukemia (CML)

Table 6 shows the number of cases examined for CML, including 35 patients who had been exposed to more than 0.01 Grays at the time of the bombing. All cases, both exposed and the non-exposed, posessed Philadelphia $\left(\mathrm{Ph}^{1}\right)$ chromosome which is characteristic for $\mathrm{CML}$. The incidence of cases with abnormal clones other than $\mathrm{Ph}^{1}$ chromosome were almost the same in both groups at about $20 \%$ of cases in the chronic phase and about $80 \%$ in the blastic phase. No specific chromosome abnormality nor tendency for formation of complex aberration were found in the exposed group.

2. Molecular studies in leukemia among A-bomb survivors.

a. Point mutation of ras oncogenes

To elucidate the mechanism of radiation induced leukemia, we studied point mutation of ras oncogenes in 25 leukemia patients with a history of atomic bomb exposure and 47 not exposed, using a polymerase chain reaction (PCR) and in vivo selection assay methods ${ }^{5)}$.

Table 7 shows the results of the PCR method and represents the number of cases examined, the number of cases with point mutations in $\mathrm{N}$ - and $\mathrm{K}$-ras genes and the number

Table 5. Abnormalities in Chromosome 5 and/or 7 in Banded Patients

\begin{tabular}{lcccc}
\hline & \multicolumn{3}{c}{ Abnormalities in chromosomes } & $\begin{array}{r}\% \text { of patients } \\
\text { with abnormalities } \\
\text { in 5 or } 7\end{array}$ \\
\hline 5 and 7 & 5 or 7 & None & 75 \\
$1.0 \sim$ & 1 & 5 & 2 & 14.3 \\
$0.01 \sim 0.99$ & 0 & 3 & 18 & 22 \\
and "exposed" & 1 & 1 & 7 & 27.6 \\
0 & 9 & 28 & 134 & \\
Nonexposed & 9 & & &
\end{tabular}

Table 6. Numbers of CML Cases Examined ${ }^{1)}$

\begin{tabular}{lrrr}
\hline $\begin{array}{l}\text { Estimatcd dose } \\
\text { (in Grays) }\end{array}$ & Chronic phase & Blastic phase & Total \\
\hline \multicolumn{1}{c}{ (2.0 } & 4 & 3 & 7 \\
$0.01-2.0$ & 18 & 10 & 28 \\
$0.01>$ & 14 & 6 & 20 \\
Non-exposed & 111 & 56 & 167 \\
\hline
\end{tabular}

1) Study period: from Sept. 1963 to March 1985.

2) T65D air dose 
Table 7. Point Mutation of Ras Oncogenes in Leukemia Patients with and without a History of Atomic Bomb Exposure (PCR Method)

\begin{tabular}{|c|c|c|c|c|c|c|c|c|}
\hline & \multirow{2}{*}{$\begin{array}{c}\text { No. of } \\
\text { cases } \\
\text { examined }\end{array}$} & \multicolumn{2}{|c|}{$\begin{array}{l}\text { ras gene } \\
\text { mutation }\end{array}$} & \multicolumn{5}{|c|}{ Number of mutated codons } \\
\hline & & $\mathbf{N}-$ & $\mathrm{K}-$ & N12 & N13 & N61 & $\mathrm{K} 12$ & K61 \\
\hline CML Exposed & 8 & 1 & 1 & 1 & & & & 1 \\
\hline Non-exposed & 25 & 2 & 2 & $1^{*}$ & 1 & $1^{*}$ & & 2 \\
\hline AML Exposed & 13 & 2 & 1 & 1 & & 1 & & 1 \\
\hline Non-exposed & 14 & 5 & 1 & 2 & & 3 & & 1 \\
\hline ALL Exposed & 4 & 0 & 0 & & & & & \\
\hline Non-cxposed & 5 & 2 & 0 & & & 2 & & \\
\hline
\end{tabular}

* the same patient

of mutated codons. Five of the 25 exposed cases, two with CML and three with AML, had point mutations in either their $\mathrm{N}$ - or $\mathrm{K}$-ras genes. In the non-exposed group, 12 cases, four with CML, six with AML and two with ALL, showed point mutations in their $\mathrm{N}$ - or K-ras genes. The distribution of the mutated codons in the 12th, 13th and 61st N- and K-ras genes and at the sites of base substitutions was similar in both groups. Thus the frequencies of $\mathrm{N}$ - or K-ras genes mutation and the sites of base substitution in the exposed group were not different from those of the non-exposed group. From a literature survey, mutations of the ras oncogenes have been found in less than $10 \%$ of CML cases and $30-40 \%$ of AML or ALL patients ${ }^{6,7,8)}$. Our results for both the exposed and the non-exposed groups corresponded well with these frequencies. The sites of base substitution found in the exposed patients were similar to those in de novo leukemia patients summarized by $\operatorname{Bos}^{9)}$. The second letter in each codon is commonly associated with the occurrence of base substitution which was also found in most of the exposed patients. These results indicate that the activation of $\mathrm{N}$ - or $\mathrm{K}$-ras oncogenes is associated with leukemogenesis, irrespective of exposure. In animal experiments the activated ras oncogenes were also found in leukemia and lymphomas induced by radiation ${ }^{10,11)}$; A consistent $\mathrm{K}$-ras mutation in mouse lymphoma induced by gamma irradiation ${ }^{12)}$; $\mathrm{N}$-ras mutation in canine acute non-lymphocytic leukemia induced by neutron irradiation ${ }^{13)}$. Aspartic acid substitution for glycine at position 12 in the ras protein has been observed. Such activation may be due to site-specific radiation damage in members of the same gene family ${ }^{13)}$. There are still some discrepancies in the findings between animal and human leukemia induced by radiation. A-bomb leukemia patients without activated $\mathrm{N}$ - or K-ras genes may have a codon mutation site other than on the $12 \mathrm{th}$, 13 th and 61st genes or may have other transforming genes such as raf, rel, met and neu.

b. bcr rearrangement in CML

bcr rearrangements in the leukemic cells of $\mathrm{CML}$ patients with $\mathrm{Ph}^{1}$ chromosome and a 
history of A-bomb exposure were studied in comparison with the non-exposed patients.

The results of DNA analyses in A-bomb survivors are shown in Table 8. All patients in the exposed group showed rearranged bands following either BamHI or BglII digestions. The band patterns by Southern blotting are shown in Fig. 1. Breakpoints within the bcr gene in each patient were determined using at least four enzymes and two probes in order to minimize misidentification due to restriction fragment length polymorphisms (RELP) or overlapping of bands with the same molecular size. There was no distinct difference between the two groups in the distribution of the breakpoints within the bcr gene. The molecular results presented here correlated well with the clinical features in the exposed group which showed no difference in the duration of the chronic phase compared to the non-exposed group. The reason for the absence of characteristic findings in the clinical, cytogenetic and molecular studies in radiation-induced leukemia is not clear. A time lapse for CML development from the A-bomb exposure would be a possibility. Most of our patients developed CML 20-40 years after exposure. CML that developed within 20 years, especially at the maximum occurrence of CML development in around 1953, might represent unique changes at the cytogenetic and molecular levels. Recently, it has become possible to use formalin-embedded paraffin blocks made 10-20 years ago for the detection of point mutation in ras oncogenes using the PCR method and for bcl-2 or myc rearrangements using Southern blotting. However, DNA obtained from paraffin blocks are not useful for

\section{A - bomb Survivors}
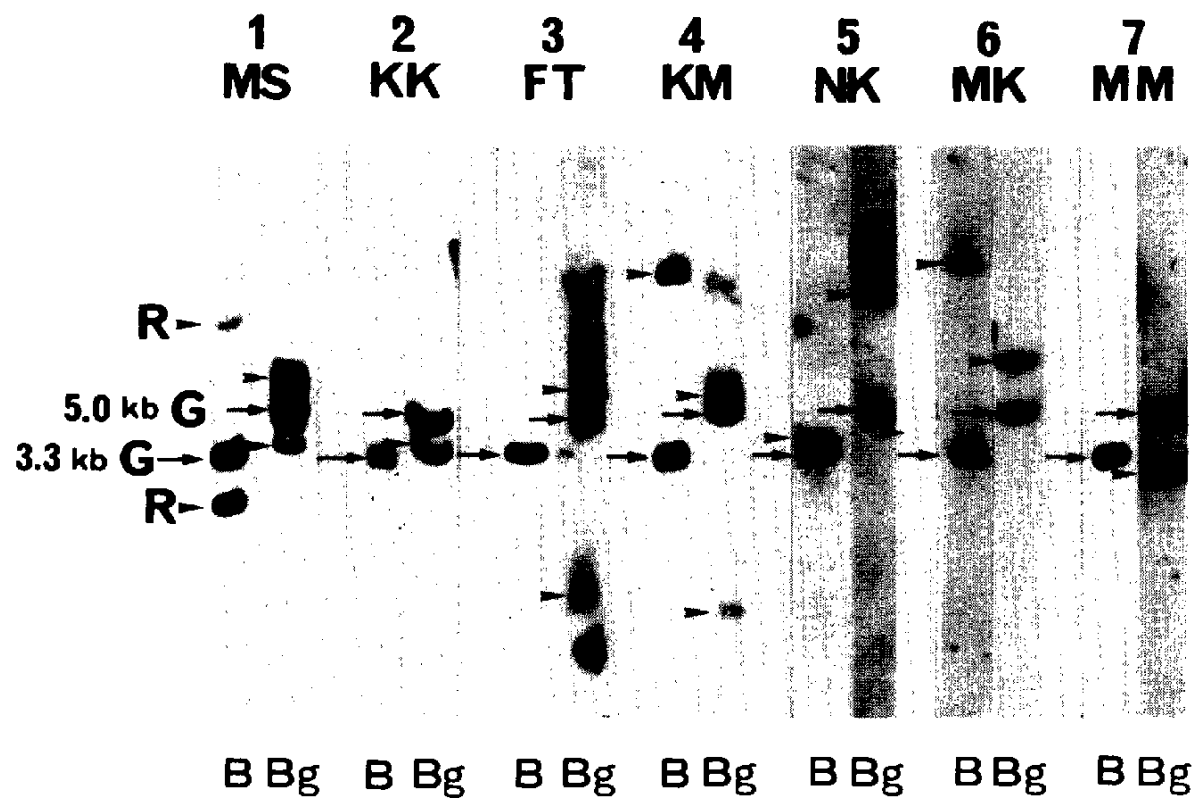
Table 8. Ph' Chromosome and bcr Rearrangement in 7 Atomic Bomb Related CML Patients

\begin{tabular}{|c|c|c|c|c|c|c|c|c|c|c|c|c|c|c|c|c|c|c|c|c|c|c|c|}
\hline \multirow{3}{*}{$\begin{array}{l}\text { Case } \\
\text { No. }\end{array}$} & \multirow[t]{3}{*}{ Sex } & \multirow{3}{*}{$\begin{array}{l}\text { Age } \\
(\mathrm{yr})\end{array}$} & \multirow{3}{*}{$\begin{array}{c}\text { Distance } \\
\text { from } \\
\text { hypoccnter } \\
(\mathrm{km})\end{array}$} & \multirow{3}{*}{$\begin{array}{l}\text { Estimated } \\
\text { T65D } \\
\text { dose } \\
\text { (rad) }\end{array}$} & \multirow{3}{*}{$\begin{array}{l}\text { Phase } \\
\text { of CML }\end{array}$} & \multirow{3}{*}{$\begin{array}{c}\text { Chromosome } \\
\text { aberration }\end{array}$} & \multicolumn{16}{|c|}{ bcr rcarrangement } & \multirow{3}{*}{$\begin{array}{l}\text { Region } \\
\text { in } \text { bcr }^{* 7}\end{array}$} \\
\hline & & & & & & & \multicolumn{5}{|c|}{ 3' ber probe } & \multicolumn{6}{|c|}{ 5' bcr probe (1) } & \multicolumn{5}{|c|}{5 bcr probe (2) } & \\
\hline & & & & & & & $\mathrm{Bg}^{* 2}$ & $\mathrm{Bm}$ & $\mathbf{H}$ & $E:$ & $S X$ & $\mathrm{Bg}$ & $\mathrm{Bm}$ & $\mathrm{H}$ & E & $\mathbf{S}$ & $\mathrm{X}$ & $\mathrm{Bg}$ & $\mathrm{Bm}$ & $\mathbf{H}$ & $\mathbf{E}$ & $\mathrm{x}$ & \\
\hline 1 & $\mathbf{M}$ & 72 & 0.7 & $400^{k 1}$ & $\mathrm{CH}^{* 3}$ & $\begin{array}{c}46, \mathrm{XY}, \mathrm{Ph}^{\mathrm{l}} \\
(\mathrm{t} 3 ; 8)\end{array}$ & $+^{*_{4}}$ & + & + & & & & & - & & & & & - & - & & & D \\
\hline 2 & M & 44 & 1.5 & - & $\mathrm{Ch} \& \mathrm{Ac}$ & $46, \mathrm{XY}, \mathrm{Ph}^{1}$ & + & + & + & + & - & $-* 6$ & & & & - & + & $-* 6$ & - & - & + & + & D \\
\hline 3 & $\mathbf{F}$ & 68 & 1.7 & - & Ch \& Ac & $46, \mathrm{XX}, \mathrm{Ph}^{1}$ & + & + & + & & ++ & $t^{* 5}$ & - & - & & & + & $t^{\prime}$ & & & & & $\mathrm{D}$ \\
\hline 4 & $\mathbf{F}$ & 51 & 2.0 & - & $\mathrm{Ch} \& \mathrm{Ac}$ & $46, \mathrm{XX}, \mathrm{Ph}^{1}$ & + & + & + & & & + & - & - & $-* 6$ & & & $+{ }^{\prime}$ & - & - & $-* 6$ & & $\mathrm{D}$ \\
\hline 5 & $\mathbf{M}$ & 51 & 2.0 & - & $\mathrm{Ch} \& \mathrm{Ac}$ & $46, \mathrm{XY}, \mathrm{Ph}^{1}$ & + & + & - & & & + & & - & & & & + & - & - & & & $\mathrm{C}$ \\
\hline 6 & $\mathbf{F}$ & 63 & 2.5 & 0 & $\mathrm{Ch}$ & $46, X X, \mathrm{Ph}^{1}$ & + & + & + & & & + & & - & & & + & & & - & & & D \\
\hline 7 & $\mathbf{M}$ & 60 & 3.0 & - & $\mathrm{Ch} \& \mathrm{Ac}$ & $46, \mathrm{XY}, \mathrm{Ph}^{1}$ & + & - & - & & & + & & + & & & & + & - & - & & & $\mathrm{B}$ \\
\hline
\end{tabular}

${ }^{* 1}$ Estimated from chromosome abarration frequency in lymphocytes

${ }^{* 2}$ Restriction enzyme, Bg: Bg1 II, Bm: BamH I, H: Hind III, E: Ecor I, S: Sst I, X: Xba I

${ }^{*} \mathrm{Ch}$ : Chronic phase, Ac: Acute phase

${ }^{*}$ Rearrangement band

*5 Rearrangement band different from that detected by 3 ber probe

* 6 Probably two bands of same size overlapping

${ }^{* 7}$ According to the regions recorded in ref. 14 
the analysis of abl/bcr rearrangement because of the specificity of rearrangement in the exon and the intron. Further development of molecular techniques are required to solve the problem of junction analysis in abl/ber materials obtained from old paraffin blocks.

\section{ACKNOWLEDGEMENT}

This work was supported in part by Grants-in-Aid for Scientific Research from the Ministry of Education, Science and Culture (01480534), from the International Scientific Research Program: Special Cancer Research (02042005), from the Scientific Promotion Found of the Ministry of Health and Public Welfare (63-3), and from the Japanese Foundation for Multi-Disciplinary Treatment of Cancer.

\section{REFERENCES}

1. Kamada, N. and Tanaka, K. (1983) Cytogenetic studies of hematological disorders in atomic bomb survivors. In: Radiation-Induced Chromosome Damage in Man. ed. by T. Ishihara and M.S. Sasaki, pp. 455-474, Alan R. Liss, New York.

2. Milton, R.C. and Shohoji, T. (1968) Tentative 1965 radiation dose estimation for atomic bomb survivors. Atomic Bomb Casualty Communication Technical Report 1-68.

3. Radiation Effects Research Foundation (1987) US-Japan Joint Reassessment of Atomic Bomb Radiation Dosimetry in Hiroshima and Nagasaki (ed. by W.C. Rocsch) RERF Printing Officc Hiroshima, Japan.

4. Bennett J.M. et al. (1976) Proposal for classification of acute leukemias. French-American-British (FAB) Co-operative group. Br. J. Haematol., 33: 451-458.

5. Tanaka, K., Takechi, M. and Kamada, N. Mutation of ras oncogenes in lcukemia patients with a history of atomic bomb exposure. (in preparation)

6. Liu, E., Hjelle, B. and Bishop, M. (1988) Transforming genes in chronic myelogenous leukemia. Proc. Natl. Acad. Sci. USA, 85: 1952-1956.

7. Jonssen, J.W.G. et al. (1987) Ras gene mutations in acute and chronic myclocytic leukemias, chronic mycloproliferative disorders, and myelodysplastic syndromes. Proc. Natl. Acad. Sci. USA. 84: 9228-9232.

8. Bos, J.L., Verlaan-de Vries M., et al. (1987) Mutations in N-ras predominate in acute myeloid leukemia. Blood 69: 1237-1241.

9. Bos, J.L. (1989) Ras oncogenes in human cancer: a review. Cancer Res., 49: 4682-4689.

10. Diamond, L.E., Guerrero, I. and Pellicer, A. (1988) Concommitant K- and N-ras gene point mutations in clonal murine lymphomas. Mol. Cell Biol., 8: 2233-2236.

11. Sloan, S.R., Newcomb, E.W. and Pellicer, A. (1990) Neutron radiation can activate K-ras via a point mutations in codon 146 and induced a different spectrum of ras mutations than does gamma radiation. Mol. Cell Biol., 10: $405-408$.

12. Guerrero, 1., Villasante, A., et al. (1984) Activation of a c-K-ras oncogene by somatic mutation in mouse lymphomas induced by gamma radiation. Science, 225: 1159-1162.

13. Gumerlock, P.H., Meycrs, F.J., et al. (1989): Activated c-N-ras in radiation-induced acute nonlymphocytic leukemia; Twelfth codon aspartic acid. Rad. Res., 117, 198-206.

14. Tanaka, K., Takcchi, M. et al. (1989) 9;22 translocation and ber rearrangements in chronic myelocytic leukemia among atomic bomb survivors. J. Radiat. Res., 30: 352-358. 